\title{
Persepsi Pembentukan Brand Awareness dan Brand Image Melalui Penerapan Integrated Marketing Communication
}

\author{
Evan Saktiendi ${ }^{1}$, Indah Restu Fauziah ${ }^{2}$ \\ ${ }^{1,2}$ Universitas Gunadarma \\ Email correspondent: vansakti@gmail.com
}

\begin{abstract}
Abstrak
Perangkat komunikasi pemasaran yang semula terpisah-pisah dan menonjolkan kelebihan masing- masing, kini mulai menggabungkan kekuatan karena memahami pentingnya keterpaduan.Penelitian ini bertujuan untuk mengetahui proses pembentukan brand awareness dan brand image di benak konsumen dari penerapan Integrated Marketing Communication dan formulasi yang tepat dari Integrated Marketing Communication untuk membentuk brand awareness dan brand image integrated marketing communication pada produk sepatu Nike. Penelitian ini menggunakan pendekatan kualitatif berdasarkan pada kerangka pemikiran yang meliputi brand awareness, brand image dan integrated marketing communication dan paradigma studi kasus. Teknik pengumpulan data yang digunakan adalah observasi dan wawancara mendalam. Kesimpulan utama dalam penelitian ini adalah bahwa penerapan integrated marketing communication pada produk Nike diindikasikan dapat membangun kesadaran merek dan citra merek, yang pada akhirnya membangun ketertarikan calon konsumen untuk menggunakan produk Nike tersebut.
\end{abstract}

Kata Kunci: brand awareness, brand image, integrated marketing communication, nike

\begin{abstract}
Marketing communication tools that were originally fragmented and highlighted each other's strengths, now begin to join forces because of understanding the importance of cohesivenessThis research aimed at knowing the process of creating brand awareness and brand image in prospective consumer's minds after implementation of Integrated Marketing Communication program in a Nike product. The research used a qualitative approach based on the conceptual frame about Nike products, brand awareness, brand image, and integrated marketing communication by using a case study paradigm. Data collection techniques used are observation and in-depth interviews. The research indicated that the implementation of Integrated Marketing Communication in the product could build brand awareness and brand image that would eventually attract prospective consumers to try the product.
\end{abstract}

Keywords: brand awareness, brand Image, integrated marketing communication, nike 


\section{Pendahuluan}

Kesehatan sangat penting bagi manusia, karena tanpa kesehatan yang baik, setiap manusia akan sulit dalam melaksanakan aktivitasnya sehari-hari. ${ }^{4}$ Pada umumnya olahraga dilakukan untuk memberikan kesehatan jasmani maupun rohani pada setiap individu yang melakukannya. Disamping manfaat tersebut ada yang melakukannya untuk menggapai prestasi, sebagai hiburan, maupun melakukannya untuk menjalani gaya hidup masa kini. Meningkatnya kesadaran berolahraga di masyarakat ditandai dengan berkembangnya sarana dan prasarana yang menunjang diantaranya seperti jogging track, klub-klub pecinta olahraga dan lain-lain. Dengan adanya peningkatan kesadaran masyarakat akan manfaat dari olahraga, menimbulkan pertumbuhan yang pesat terhadap industri sepatu olahraga. Kenyataan ini merupakan peluang yang dimanfaatkan oleh produsen sepatu dengan mengeluarkan berbagai jenis dan merek yang dikeluarkan di Indonesia. ${ }^{5}$

Philip Kotler ${ }^{6}$ mengemukakan bahwa produk adalah sesuatu yang ditawarkan ke dalam pasar untuk diperhatikan, dimiliki, dipakai atau dikonsumsi sehingga dapat memuaskan keinginan atau kebutuhan konsumen. Kualitas produk adalah keadaan fisik, fungsi, dan sifat suatu produk bersangkutan yang dapat memenuhi selera dan kebutuhan konsumen dengan memuaskan sesuai nilainya. ${ }^{10}$

Keputusan untuk membeli suatu produk sangat dipengaruhi oleh penilaian akan kualitas produk tersebut. Merek mempunyai sifat khas, dan sifat khas inilah yang membedakan produk yang satu berbeda dengan produk yang lainnya. Keputusan pembelian merupakan suatu keputusan sebagai pemilihan suatu keputusan sebagai pemilihan suatu tindakan dari dua atau lebih pilihan alternatif. ${ }^{11}$

Perilaku konsumen merupakan tindakan yang dilakukan sesorang ketika mendapatkan, mengkonsumsi, dan menghabiskan sebuah produk atau jasa, termasuk dalam memikirkan tindakan apa yang akan dilakukan pada saat menjalani proses keputusan-keputusan. Proses pembelian yang lebih lengkap terdiri dari pengenalan masalah kebutuhan, pencarian informasi, evaluasi alternative, keputusan pembelian dan perilaku pasca pembelian. ${ }^{12}$

Pada zaman modern saat ini, salah satu industri yang tumbuh pesat adalah industry sepatu olahraga. Hal ini terjadi karena tumbuhnya peningkatan kesadaran masyarakat akan manfaat dari olahraga. Maka dari itu penulis tertarik meneliti salah satu perusahaan sepatu, pakaian dan alat-alat olahraga yang berasal dari Amerika Serikat yang merupakan salah satu perusahaan terbesar di dunia yaitu Nike. Kota Bogor menjadi tempat dimana peneliti dilakukan Publisitas, Berbagai program untuk mempromosikan dan/atau melindungi citra perusahaan atau produk individualnya.

Penjualan Personal, interaksi langsung dengan satu calon pembeli atau lebih untuk melakukan presentasi, menjawab pertanyaan, dan menerima pesanan. ${ }^{1}$ Pemasaran Langsung, Penggunaan surat, telepon, faksimili, email, dan alat penghubung nonpersonal lain untuk berkomunikasi secara langsung dengan/atau mendapatkan tanggapan langsung dari pelanggan tertentu dan calon pelanggan. ${ }^{2}$ Acara dan Pengalaman, merupakan pengembangan publisitas yang mengacu pada pengadaan kegiatan organisasional yang sifatnya mendukung promosi, misalnya pensponsoran. ${ }^{5}$

\section{Metode}

Penelitian ini menggunakan metode deskriptif kualitatif dengan menganalisis brand awareness dan brand image dari penerapan Integrated Marketing Communication (IMC) pada Produk yang dilakukan penelitian kualitatif, penelitian kualitatif pada hakekatnya adalah penelitian yang memanfaatkan wawancara terbuka untuk menelaah dan memahami sikap, pandangan, perasaan, dan perilaku individu atau sekelompok orang. ${ }^{8}$ Pemilihan pendekatan kualitatif pada penelitian ini didasari karena peneliti ingin memperoleh kedalaman jawaban untuk mengetahui informasi mengenai pembentukan brand awareness dan brand image di benak konsumen, khususnya pengguna running shoes merek Nike pada kalangan pelari di Kota Bogor. ${ }^{9}$

Responden yang diteliti dalam penelitian ini adalah kalangan pelari yang berada di daerah Bogor 
yang telah membeli dan menggunakan produk sepatu Nike. Peneliti juga mengambil data melalui media internet dan buku. Penelitian ini menggunakan triangulasi data yaitu data hasil wawancara, observasi, dan dokumen.

Paradigma yang digunakan dalam penelitian ini yaitu post-positivistik Paradigma postpositivistik merupakan aliran yang ingin memperbaiki kelemahan-kelemahan positivisme yang hanya mengandalkan kemampuan pengamatan langsung terhadap objek. Penelitian post- positivistik menggunakan berbagai metode dalam penelitiannya, sambil tetap menekankan penemuan dan pembuktian teori. ${ }^{14}$ Meskipun peneliti mengambil posisi objektif, namun mereka menyadari bahwa interaksi peneliti dan partisipan akan mempengaruhi data. ${ }^{15}$

Penelitian ini menggunakan studi kasus.Menurut Daymon \& Holloway studi kasus merupakan sebuah pengujian intensif menggunakan berbagai sumber bukti (yang bisa jadi kualitatif, kuntitatif, atau keduanya) yang dibatasi oleh ruang dan waktu. Kasus yang diangkat dapat berupa sebuah organisasi, sekumpulan orang atau kelompok kerja,komunitas, peristiwa, proses, isu, maupun kampanye. $^{3}$

\section{Hasil dan Pembahasan}

Tujuan utama dari penerapan Integrated Marketing Communication yang dilakukan oleh Nike adalah untuk membangun nama merek perusahaan itu sendiri. Dimana dalam membangun hal tersebut dibutuhkan brand awareness dan brand image yang tentunya bersifat positif tehadap produk yang ditawarkan. Dari penelitian yang dilakukan, diperoleh jawaban bahwa informan mengetahui produk Nike tanpa harus diingatkan terlebih dahulu. Keempat informan juga dapat menjelaskan mengenai produk Nike dan hal tersebut membuktikan bahwa penerapan Integrated Marketing Communication dalam membangun brand awarenees sudah mampu berjalan dengan baik.

Dari jawaban seluruh informan yang diperoleh mengatakan bahwa melalui media komunikasi, informan mampu mempersepsikan bahwa produk Nike nyaman digunakan pada saat melakukan kegiatan race dalam kategori half marathon, full marathon bahkan ultra marathon yang bisa mencapai $100 \mathrm{~km}$ jaraknya. Ketika memutuskan untuk membeli sepatu Nike, beberapa informan mengatakan bahwa ia tidak memiliki informasi detail mengenai sepatu tersebut melalui pelari lain yang menggunakan sepatu yang sama. Informan merasa cukup dengan informasi yang diberikan melalui website, bahkan youtube yang memiliki durasi lebih lama dalam mengenalkan produk tersebut melalui video. Hal tersebut membuktikan bahwa brand image produk ini telah dibangun secara positif. Selain itu informan mempercayai merek besar Nike yang sudah terkenal dan digunakan oleh atlit dunia dalam yang berhasil menjuari setiap kompetisi olahraga.

Komunikasi pemasaran adalah sarana yang digunakan perusahaan dalam upaya menginformasikan, membujuk, dan mengingatkan konsumen tentang merek yang dijual. Maka sangat jelas bahwa segala perangkat medua komunikasi yang dibuat bertujuan untuk memperoleh kesadaran, serta citra merek yang baik dimata konsumen. Berdasarkan hasil penelitian Brand Awareness dan Brand Image melalui penerapan Integrated Marketing Communication pada produk Nike yang telah dibahas pada bab sebelumnya, maka peneliti menarik beberapa kesimpulan yang dapat menjawab pertanyaan penelitian yang telah di paparkan sebelumnya, yaitu :

Konsumen menaruh kepercayaan lebih kepada perusahaan, dikarenakan melalui terbentuknya kesadaran merek dan citra postif dari produk Nike yang diuncurkan. Hal tersebut memungkinkan terjadinya hubungan jangka panjang yang saling menguntungkan dan pada akhirnya memudahkan konsumen untuk membeli produk dari inovasi selanjutnya.

Faktor yang menjadikan konsumen tertarik terhadap produk Nike salah satunya adalah Brand Ambassador yang dimiliki Nike mampu memberikan dampak besar dalam mencapai kesadaran dan citra merek positif produk Nike. Konsumen juga bisa mengetahui produk Nike lebih detail melalui akun media sosial yang dimiliki oleh Brand Ambassador Nike, hal tersebut memudahkan konsumen dalam 


\section{JIKOM \\ Jurnal Ilmiah Komunikasi}

Volume 12, No.02, Juli. 2020

memperoleh informasi mengenai produk Nike. Konsumen pun paham mengenai pesan yang disampaikan oleh perusahaan melalui berbagai macam promosi salah satunya melalui akun dari Brand Ambassador yang dimiliki oleh Nike.

Konsumen dapat mengetahui dan memahami produk tersebut melalui ciri khas yang dimiliki oleh Nike yaitu adanya simbol- simbol dan warna yang menarik di berbagai perangkat komunikasi dalam memperkenalkan produknya.

Hasil penelitian ini membenarkan juga teori yang dikemukakan oleh Kitchen et al yang mengatakan bahwa IMC bukan lagi hanya sebuah proses komunikasi, tetapi sebuah proses yang terkait dengan pengelolaan sebuah merek. Maka dari itu hubungan antara strategi komunikasi pemasaran yang tepat, citra merek yang positif, dan kualitas produk yang ditawarkan sangatlah penting.

Ide pokok mengenai Marketing Mix yang termasuk bagian dari komunikasi pemasaran terpadu atau Integrated Marketing Communications (IMC) yaitu komunikasi pemasaran yang bersifat onevoice, maksudnya adalah walau elemen komunikasi pemasaran yang digunakan berbeda-beda dalam menarik pihak sponsorship dan bekerjasama denganpihak media. Jadi pihak Persebaya meskipun menggunakan pemasaran dan promosi dengan menggunakan media yang berbedabeda dalam menarik sponsorship tetapi tetap saja semuanya sudah terkonsep dan tertata dengan baik.

\section{Product (Produk)}

Produk merupakan setiap apa saja yang bisa ditawarkan dipasar untuk mendapatkan perhatian, permintaan, pemakaian atau konsumsi yang dapat memenuhi keinginan atau kebutuhan. Produk tidak hanya selalu berupa barang tetapi bisa juga berupa jasa ataupun gabungan dari keduanya (barang dan jasa). Produk merupakan kombinasi barang dan jasa yang di tawarkan perusahaan kepada pasar sasaran. Produk tidak hanya meliputi unit fisiknya saja tetapi juga kemasan, garansi, merek, dan pelayanan saat menjual.

\section{Price (Harga)}

Penetapan harga merupakan suatu hal penting. Perusahaan akan melakukan hal ini dengan penuh pertimbangan karena penetapan harga akan dapat mempengaruhi pendapatan total dan biaya. Harga merupakan faktor utama penentu posisi dan harus diputuskan sesuai dengan pasar sasaran, bauran ragam produk, dan pelayanan, serta persaingan.

\section{Place (Tempat)}

Tempat atau lokasi yang strategis akan menjadi salah satu keuntungan bagi perusahaan karena mudah terjangkau oleh konsumen namun sekaligus juga menjadikan biaya rental atau investasi tempat menjadi semakin mahal. Tingginya biaya lokasi tersebut dapat diganti dengan mengurangi biaya pemasaran, sebaliknya lokasi yang kurang strategis akan membutuhkan biaya pemasaran lebih mahal untuk menarik konsumen agar berkunjung. Dekorasi dan desain sering menjadi daya tarik tersendiri bagi para target konsumen. Kondisi bangunan juga menjadi persyaratan yang memberikan kenyamanan.

\section{Promotion (Promosi)}

Promosi merupakan suatu aktivitas dan materi yang dalam aplikasinya menggunakan teknik, dibawah pengendalian penjual/produsen, yang dapat mengkomunikasikan informasi persuasif yang menarik tentang produk yang ditawarkan oleh penjual/produsen, baik secara langsung maupun melalui pihak yang dapat mempengaruhi pembelian.

Tujuan kegiatan promosi antara lain : (1) Mengidentifikasi dan menarik konsumen baru. (2) Mengkomunikasikan produk baru. (3) Meningkatkan jumlah konsumen untuk produk yang telah dikenal secara luas. (4) Menginformasikan kepada konsumen tentang peningkatan kualitas produk. (5) 


\section{JIKOM \\ Jurnal Ilmiah Komunikasi}

Volume 12, No.02, Juli. 2020

Mengajak konsumen untuk mendatangi tempat penjualan produk (6) Memotivasi konsumen agar memilih atau membeli suatu produk.

\section{Kesimpulan}

Nike menerapkan strategi komunikasi pemasaran yang tepat, citra merek yang positif dan kualitas produk yang ditawarkan sangatlah penting.

\section{References}

1. Aaker, David. Manajemen Ekuitas Merek. Jakarta: Spektrum. 1997.

2. Agus, Hermawan. Komunikasi Pemasaran. Jakarta: Erlangga. 2012

3. Daymon. Christine, Holloway, Immy.. Metode- Metode Riset Kualitatif. Jakarta: Benteng Pustaka.2008

4. Durianto, Darmadi. Brand Equity Ten Strategi Memimpin Pasar. Gramedia Pustaka Utama, 2004

5. Engel, Blackwell, dan Miniard. 1994. Perilaku Konsumen. Jakarta: Binarupa Aksara. 1994.

6. Kotler, Philip. Manajemen Pemasaran. Edisi 11, Jakarta: Indeks kelompok Gramedia. Muhammad.2003.

7. Romadhoni,.Pengaruh Citra Merek (Brand Image) Terhadap Pengambilan Keputusan Pembelian Sepatu Nike Pada Mahasiswa FIK UNY. Jurnal Ilmu Keolahragaan, 2-3. 2015

8. Moleong. Metodologi Penelitian Kualitatif. Bandung: PT Remaja Rosdakarya. 2007

9. Moelong, J. "Lexy. 2004." Metodologi Penelitian Kualitatif. Bandung, Rosda Karya.

10. Schiffman, Kanuk Consumer Behavior, 10 Edition, Singapore:Prentice Hall. Shimp, . 2012.

11. Shimp,Terence A.. Periklanan Promosi: Aspek Tambahan Komunikasi Pemasaran Terpadu. Jakarta: Erlangga. 2003.

12. Setiadi, J. "Nugroho. 2003." Perilaku Konsumen

13. Prawirosentono, Suyadi. Filosofi Baru Tentang Manajemen Mutu Terpadu Total Quality Management Abad 21, Jakarta : Bumi Aksara. 2004.

14. Poerwandari, E. Kristi. Pendekatan kualitatif untuk penelitian perilaku manusia. LPSP3 Fakultas Psikologi Universitas Indonesia, 2007.

15. POERWANDARI, E. Kristi. Pendekatan kualitatif. Depok:(Penerbit Lembaga Pengembangan Sarana Pengukurandan Pendidikan Psikologi, 2007 